\title{
KOMPARASI FONEM BAHASA SUNDA DAN BAHASA INDONESIA DALAM BUKU TEKS
}

\author{
Lutfi Syauki Faznur ${ }^{1)}$, Didah Nurhamidah ${ }^{2)}$ \\ ${ }^{1)}$ Pendidikan Bahasa dan Sastra Indonesia, Fakultas Ilmu Pendidikan, \\ Universitas Muhammadiyah Jakarta \\ ${ }^{2)}$ Pendidikan Bahasa dan Sastra Indonesia, Fakultas Ilmu Tarbiyah dan Keguruan, \\ Universitas Islam Negeri Syarif Hidayatullah Jakarta \\ Email: Lutfisyauki@umj.ac.id dan didah.nurhamidah@uinjkt.ac.id
}

\begin{abstract}
ABSTRAK
Penelitian ini bertujuan untuk mendeskripsikan sistem fonologi bahasa Sunda, sistem fonologi bahasa Indonesia, serta perbedaan-perbedaan sistem fonologi yang terdapat pada kedua bahasa tersebut. Tempat penelitian tidak terikat pada satu tempat karena objek yang dikaji berupa buku teks yaitu buku teks bahasa Indonesia dan bahasa Sunda. Bentuk penelitian ini adalah deskriptif kualitatif dengan metode content analysis. Hasil penelitian ini menunjukan bahwa fonem yang terdapat pada bahasa Sunda terdapat tujuh buah sedangkan dalam bahasa Indonesia terdapat lima vokal. Pengklasifikasian jenis vokal dapat ditentukan oleh tiga hal, yaitu: posisi bibir, maju-mundurnya lidah, dan tinggi rendahnya lidah. Terdapat 18 konsonan dalam bahasa sunda sedangkan dalam bahasa Indonesia ada 21 konsonan. Pengklasifikasian kosonan dapat ditentukan oleh tiga hal, yaitu: keadaan pita suara, artikulator dan titik artikulasi. Deretan vokal bahasa sunda ada 29 buah. Tetapi, ada sebagian vokal yang tidak bisa berderet dengan vokal-vokal lainnya, Sedangkan dalam bahasa Indonesia, kata yang memiliki deretan kata disebut dengan diftong.
\end{abstract}

Kata Kunci: kata, bahasa Sunda, bahasa Indonesia, fonologi

\section{PENDAHULUAN}

Bahasa-bahasa daerah di Indonesia mempunyai pengaruh dalam pembentukan dan pengembangan bahasa Indonesia. Sebelum mengenal bahasa Indonesia sebagian besar bangsa Indonesia mempelajari dan menggunakan bahasa daerah dalam interaksi kehidupan masyarakat. Ucapan dan cara penyampaian ide-ide dipengaruhi kebiasaan yang lazim digunakan oleh masyarakat itu. Bahasa daerah tetap dipelihara oleh negara sebagai bagian kebudayaan yang hidup.

Bahasa Indonesia merupakan bahasa kedua sedangkan bahasa pertama adalah bahasa ibu, yaitu bahasa daerah, seperti bahasa Jawa, Sunda, Aceh, Batak, Minangkabau, Bali dan masih banyak lagi 
Lutfi Syauki Faznur ${ }^{1)}$, Didah Nurhamidah²): Komparasi Fonem Bahasa Sunda dan Bahasa Indonesia Dalam Buku Teks

Website : https://jurnal.umj.ac.id/index.php/penaliterasi Email :penaliterasi@umj.ac.id

yang lain. Dalam realitanya bahasa daerah sangat berperan penting dalam perkembangan dan pertumbuhan bahasa Indonesia yang kita gunakan.

Pembelajaran bahasa kedua seringkali dihadapkan pada kesulitankesulitan yang ditimbulkan oleh asumsiasumsi pembelajar yang terbawa dari bahasa pertama atau bahasa ibu. Hal ini dapat diantisipasi dengan pengontrasan bahasa pertama atau bahasa ibu dengan bahasa kedua agar dapat tergambar hal-hal apa saja yang dapat menjadi hambatan dalam pembelajaran bahasa kedua.

Pengontrasan bahasa pertama atau bahasa ibu dengan bahasa kedua dapat dilakukan dengan analisis kontrastif. Analisis Kontrastif (Contrastive Analysis) adalah sebuah metode yang digunakan dalam mencari suatu perbedaan antara bahasa pertama (B1) dan bahasa target (B2) yang sering membuat pembelajar bahasa kedua mengalami kesulitan dalam memahami suatu materi bahasa kedua yang dipelajarinya tersebut. Secara umum memahami pengertian analisis kontrastif dapat diartikan sebagai semacam pembahasan atau uraian. Yang dimaksud dengan pembahasan adalah proses atau cara membahas yang bertujuan untuk mengetahui sesuatu dan memungkinkan dapat menemukan inti permasalahannya. Permasalahan yang ditemukan itu kemudian dikupas, dikritik. diulas, dan akhirnya disimpulkan untuk dipahami.

Menurut (Pranowo, 1996) Analisis kontrastif sering dipersamakan dengan istilah linguistik kontrastif. Linguistik kontrastif adalah suatu cabang ilmu bahasa yang tugasnya membandingkan secara sinkronis dua bahasa sedemikian rupa sehingga kemiripan dan perbedaan kedua bahasa itu bisa dilihat. Analisis kontrastif diharapkan dapat mengidentifikasikan perbedaan struktur bahasa pertama dengan bahasa kedua dan memperkirakan kesulitan dan kesalahan berbahasa. Setelah kedua harapan diatas terpenuhi diharapkan dengan adanya analisis kontrastif hambatanhambatan yang muncul pada pembelajaran bahasa kedua dapat teratasi.

Dalam pembelajaran, ketika siswa berbicara bahasa ibu terkadang masih terbawa di kelas, banyak sekali bunyi-bunyi khas dari bahasa ibu tidak bisa dihilangkan oleh seorang siswa. Maka dalam makalah ini akan dipaparkan beberapa perbedaan segi fonologi atau pengucapan bahasa sunda yang harus diketahui berbeda dengan bahasa Indonesia. Namun kenyataan yang terjadi, hal tersebut diianggap tidak penting oleh sebagian pengajar, sehingga mereka terkadang tidak ingin menganggapnya menjadi hal yang serius.

Fonologi secara etimologi terbentuk dari kata fon yaitu bunyi, dan logi yaitu ilmu. Fonologi adalah bidang linguistik yang mempelajari, menganalisis, dan membicarakan runtutan bunyi-bunyi bahasa (Chaer, 2007). Menurut hierarki satuan bunyi yang menjadi objek studinya, fonologi dibedakan menjadi fonetik dan fonemik.

Fonetik adalah ilmu bahasa yang membahas bunyi-bunyi bahasa yang dihasilkan alat ucap manusia, serta bagaimana bunyi itu dihasilkan. Sedangkan Fonemik adalah ilmu bahasa yang membahas bunyi-bunyi bahasa yang berfungsi sebagai pembeda makna (Chaer, 2007). Jika dalam fonetik kita mempelajari segala macam bunyi yang dapat dihasilkan oleh alat-alat ucap serta bagaimana tiap-tiap bunyi itu dilaksanakan, maka dalam fonemik kita mempelajari dan menyelidiki kemungkinan, bunyi ujaran yang manakah yang dapat mempunyai fungsi untuk membedakan arti.

Klasifikasi vokal atau bunyi vokal biasanya diklasifikasikan dan diberi nama berdasarkan posisi lidah dan bentuk mulut. Posisi lidah bisa bersifat vertikal dan 
Lutfi Syauki Faznur ${ }^{1)}$, Didah Nurhamidah²): Komparasi Fonem Bahasa Sunda dan Bahasa Indonesia Dalam Buku Teks

Website : https://jurnal.umj.ac.id/index.php/penaliterasi Email :penaliterasi@umj.ac.id

horizontal. Secara vertiakal dibedakan menjadi vokal tinggi, misal, bunyi /i/ dan /u/. Vokal tengah misalnya, bunyi /e/ dan / Ә/ dan vokal rendah misalnya /a/. Secara horizontal dibedakan adanya vokal depan misal. Bunyi /e/ dan /i/; vokal pusat misalnya bunyi /Ә/; dan vokal belakang misalnya bunyi /u/ dan /o/. Kemudian menurut bentuk mulut dibedakan adanya vokal bundar dan vokal tak bundar. Disebut vokal bundar karena bentuk mulut membundar ketika mengucapkan vokal itu, misal bunyi vokal /u/ dan /o/. Disebut vokal tak bundar karena bentuk mulut tidak membundar, melainkan melebar pada waktu pengucapan vokal misal /e/ dan /i/.

Distribusi vokal lebih lanjut dijelaskan melalui tabel di bawah ini.

Tabel 1

Posisi Vokal Dalam Fonem

\begin{tabular}{|c|c|c|c|}
\hline \multicolumn{4}{|c|}{ Posisi } \\
\hline $\begin{array}{l}\text { Fone } \\
\text { m }\end{array}$ & Awal & Tengah & Akhir \\
\hline $\begin{array}{l}\mathrm{li} / \\
\mathrm{le} / \\
\mathrm{l} / \mathrm{d} / \\
\mathrm{la} \\
\mathrm{lu} / \\
\mathrm{lo} /\end{array}$ & $\begin{array}{l}\text { /ikan/ ik } \\
\text { an } \\
\text { /ekor/ ek } \\
\text { or } \\
\text { /Omas/ e } \\
\text { mas } \\
\text { /anak/ a } \\
\text { nak } \\
\text { /ukir/ uk } \\
\text { ir } \\
\text { /obat/ ob } \\
\text { at }\end{array}$ & $\begin{array}{l}\text { /pintu/ pin } \\
\text { tu } \\
\text { /nenek/ ne } \\
\text { nek } \\
\text { /ruwot/ ru } \\
\text { wet } \\
\text { /darma/ da } \\
\text { rma } \\
\text { /masuk/ m } \\
\text { asuk } \\
\text { /balon/ bal } \\
\text { on }\end{array}$ & $\begin{array}{l}\text { /api/api } \\
\text { /sore/ s } \\
\text { ore } \\
\text { /tipe } / \mathrm{t} \\
\text { ipe } \\
\text { /kota/ k } \\
\text { ota } \\
\text { /bau/ ba } \\
\mathrm{u} \\
\text { /baso/ b } \\
\text { aso }\end{array}$ \\
\hline
\end{tabular}

Sedangkan, Klasifikasi konsonan atau bunyi konsonan biasanya dibedakan berdasarkan tiga patokan atau kriteria, yaitu posisi pita suara, tempat artikulasi, dan cara artikulasi. Berdasarkan pita suara dibedakan adanya bunyi bersuara dan tidak bersuara. Bunyi bersuara terjadi apabila pita suara hanya terbuka sedikit, sehingga terjadilah getaran pada pita suara tersebut. Yang termasuk bunyi bersuara antara lain: /b/, /d/, /g/,dan /c/. Bunyi tak bersuara terjadi bila pita suara terbuka agak lebar, sehingga tidak ada getaran suara pada pita suara itu. Yang termasuk bunyi tak bersuara antara lain: /s/, $/ \mathrm{k} /, \mathrm{p} /$, dasn $/ \mathrm{t} /$.

Distribusi konsonan lebih lanjut dijelaskan melalui tabel di bawah ini.

Tabel 2

Posisi Konsonan Dalam Fonem

\begin{tabular}{|c|c|c|c|}
\hline \multicolumn{4}{|l|}{ Posisi } \\
\hline Fonem & Awal & Tengah & Akhir \\
\hline$/ \mathrm{p} /$ & /pasang/ & /apa/ & /siap/ \\
\hline$/ \mathrm{b} /$ & /bahasa/ & /sebut/ & /adab/ \\
\hline$/ \mathrm{t} /$ & /tali/ & /mata/ & /rapat/ \\
\hline /d/ & /dua/ & /ada/ & /abad/ \\
\hline /c/ & /cakap/ & /beca/ & - \\
\hline /j/ & /jalan/ & /manja/ & /mi'raj/ \\
\hline$/ \mathrm{k} /$ & /kami/ & /paksa/ & /politik/ \\
\hline /g/ & /galag/ & /tiga/ & /jajag/ \\
\hline /f/ & /fakir/ & /kafan/ & /maaf/ \\
\hline /v/ & /varia/ & /lava/ & - \\
\hline /s/ & /suku/ & /asli/ & /lemas/ \\
\hline |z/ & /zeni/ & /lazim/ & - \\
\hline$/ \check{\mathbf{S}} /$ & /syarat/ & /isyarat/ & /arasy/ \\
\hline$/ \mathrm{h} /$ & /hari/ & /lihat & /tanah/ \\
\hline$/ \mathrm{m} /$ & /maka/ & /kami/ & /diam/ \\
\hline$/ \mathrm{n} /$ & /nama/ & /anak/ & /daun/ \\
\hline$/ \check{\mathrm{n}} /$ & /nyata/ & /hanya/ & - \\
\hline$/ \mathrm{n} /$ & /ngilu/ & /angin/ & /pening/ \\
\hline$/ \mathrm{r} /$ & /raih/ & /juara/ & /putar/ \\
\hline$/ 1 /$ & /lekas/ & /alas/ & /kesal/ \\
\hline$/ \mathrm{w} /$ & /wanita/ & /hawa/ & - \\
\hline /y/ & /yakin/ & /payung/ & - \\
\hline
\end{tabular}

Menurut (Pusat Pembinaan dan Pengembangan Bahasa, 1983), fonemis dalam bahasa sunda terdiri dari konsonan dan vokal, distribusi konsonan dan vokal,

serta deretan vokal dan konsonan. Terdapat tujuh buah vokal dalam bahasa sunda, yaitu:

$$
\text { /a/ }[\mathrm{a}], / \mathrm{i} /[\mathrm{i}], / \mathrm{u} /[\mathrm{u}], / e ́ \text { / }
$$

$[\varepsilon], / o /[o], / e u /[\ddot{o}], \operatorname{dan} / \mathrm{e} /[\mathrm{c}]$.

\section{Klasifikasi Vokal Bahasa Sunda}


Lutfi Syauki Faznur ${ }^{1)}$, Didah Nurhamidah²): Komparasi Fonem Bahasa Sunda dan Bahasa Indonesia Dalam Buku Teks

Website : https://jurnal.umj.ac.id/index.php/penaliterasi Email :penaliterasi@umj.ac.id

\begin{tabular}{|c|c|c|c|c|c|c|c|c|c|}
\hline \multicolumn{2}{|c|}{$\begin{array}{l}\text { Posisi } \\
\text { ibir }\end{array}$} & \multicolumn{4}{|c|}{$\begin{array}{l}\text { Maju- } \\
\text { Mundurnya } \\
\text { Lidah }\end{array}$} & \multicolumn{4}{|c|}{$\begin{array}{l}\text { Tinggi- } \\
\text { Rendahnya } \\
\text { Lidah }\end{array}$} \\
\hline $\begin{array}{l}\text { Bul } \\
\text { at }\end{array}$ & $\begin{array}{l}\text { Tak } \\
\text { Bula } \\
\mathrm{t}\end{array}$ & $\begin{array}{l}\text { De } \\
\text { pan }\end{array}$ & \multicolumn{2}{|c|}{$\begin{array}{l}\text { Pusa } \\
\mathrm{t}\end{array}$} & $\begin{array}{l}\text { Bela } \\
\text { kang }\end{array}$ & $\begin{array}{l}\text { Tin } \\
\text { ggi }\end{array}$ & & $\begin{array}{l}\text { Ten } \\
\text { gah }\end{array}$ & $\begin{array}{l}\mathrm{Re} \\
\mathrm{nda} \\
\mathrm{h}\end{array}$ \\
\hline $\mathrm{O}$ & $\mathrm{A}$ & I & \multicolumn{2}{|c|}{ A } & $\mathrm{U}$ & $\mathrm{i}$ & & $\mathrm{E}$ & $\mathrm{a}$ \\
\hline $\mathrm{U}$ & $\mathrm{I}$ & $E$ & \multicolumn{2}{|c|}{$\mathrm{C}$} & $\mathrm{O}$ & $\ddot{0}$ & & $\mathrm{C}$ & \\
\hline \multirow[t]{3}{*}{ Cakup } & ${ }^{\mathrm{n}^{\text {Artiku }}}$ & $\mathrm{S} 1$ & \multicolumn{2}{|c|}{ Ö } & Artil & \multicolumn{2}{|c|}{ ulator } & $\mathrm{O}$ & \\
\hline & Ö & & & & $\mathrm{D}$ & & & & \\
\hline & $\mathrm{C}$ & & & $\mathrm{L}$ & $\mathrm{e}$ & & & & \\
\hline & & & $\begin{array}{l}\mathrm{B} \\
\mathrm{i} \\
\mathrm{l} \\
\mathrm{a} \\
\mathrm{b} \\
\mathrm{i} \\
\mathrm{a} \\
1\end{array}$ & $\begin{array}{l}\mathrm{a} \\
\mathrm{b} \\
\mathrm{i} \\
\mathrm{o} \\
\mathrm{d} \\
\mathrm{e} \\
\mathrm{n} \\
\mathrm{t} \\
\mathrm{a} \\
\mathrm{l}\end{array}$ & $\begin{array}{l}\mathrm{t} \\
\mathrm{a} \\
\mathrm{l} \\
\mathrm{A} \\
\mathrm{l} \\
\mathrm{v} \\
\mathrm{e} \\
\mathrm{o} \\
\mathrm{l} \\
\mathrm{a} \\
\mathrm{r}\end{array}$ & $\begin{array}{l}\mathrm{P} \\
\mathrm{a} \\
\mathrm{l} \\
\mathrm{a} \\
\mathrm{t} \\
\mathrm{a} \\
1\end{array}$ & $\begin{array}{l}\mathrm{V} \\
\mathrm{e} \\
1 \\
\mathrm{a} \\
\mathrm{r}\end{array}$ & $\begin{array}{l}\mathrm{L} \\
\mathrm{a} \\
\mathrm{r} \\
\mathrm{i} \\
\mathrm{n} \\
\mathrm{g} \\
\mathrm{a} \\
1\end{array}$ & $\begin{array}{l}\mathrm{G} \\
1 \\
\mathrm{o} \\
\mathrm{t} \\
\mathrm{a} \\
1\end{array}$ \\
\hline \multirow{2}{*}{\multicolumn{2}{|c|}{ Stop }} & $\begin{array}{l}\mathrm{T} \\
\mathrm{B} \\
\end{array}$ & $P$ & & $\mathrm{~T}$ & $\mathrm{C}$ & K & & $?$ \\
\hline & & B & B & & $\mathrm{D}$ & $\mathrm{J}$ & $\mathrm{G}$ & & \\
\hline \multirow{2}{*}{\multicolumn{2}{|c|}{$\begin{array}{l}\text { Geser } \\
\text { Frekatif }\end{array}$}} & $\begin{array}{l}\mathrm{T} \\
\mathrm{B} \\
\end{array}$ & & (f) & $S$ & & & $\mathrm{~h}$ & \\
\hline & & B & & (v & (z) & & & & \\
\hline \multicolumn{2}{|c|}{ Lateral } & B & & & $\mathrm{L}$ & & & & \\
\hline \multicolumn{2}{|c|}{ Getar } & B & & & $\mathrm{R}$ & & & & \\
\hline \multicolumn{2}{|c|}{ Nasal } & B & $\mathrm{M}$ & & $\mathrm{N}$ & $\tilde{\mathrm{N}}$ & $\mathrm{H}$ & & \\
\hline Semi & okal & B & & $\mathrm{W}$ & & $\mathrm{Y}$ & & & \\
\hline
\end{tabular}

Sedangkan, konsonan dalam bahasa

Sunda teerdapat 18 konsonan, yaitu /b/ [b], /c/ [c], /d/ [d], /g/ [g], /h/ [h], $/ \mathrm{j} /[\mathrm{j}], / \mathrm{k} /[\mathrm{k}], / \mathrm{l} /[\mathrm{l}], / \mathrm{m} /[\mathrm{m}], / \mathrm{n} /$ $[\mathrm{n}], / \mathrm{ny} /[\tilde{\mathrm{n}}], / \mathrm{ng} /[\eta], / \mathrm{p} /[\mathrm{p}], / \mathrm{r} /$ $[\mathrm{r}], / \mathrm{s} /[\mathrm{s}], / \mathrm{t} /[\mathrm{t}], / \mathrm{w} /[\mathrm{w}], \mathrm{dan} / \mathrm{y} /$ [y]. Namun, akibat pengaruh bahasa asing,

dalam bahasa Sunda pun adanya konsonan /f/ [f], /v/ [v], dan /z/ [z].

\section{Klasifikasi Konsonan Bahasa Sunda}

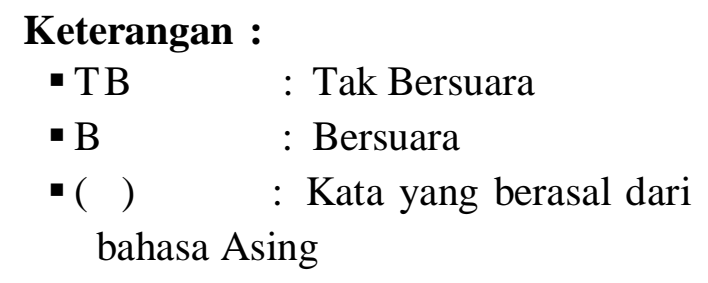

Berdasarkan masalah di atas, penulis merasa tertarik untuk meneliti perbandingan fonologi dalam bahasa Sunda dan bahasa Indonesia.

\section{METODOLOGI PENELITIAN}

Metode penelitian ini adalah deskriptif kualitatif. Menurut (Bogdan dan Taylor dalam Moleong, 2007) metode penelitian kualitatif adalah prosedur penelitian yang menghasilkan data deskriptif berupa kata-kata tertulis atau lisan dari orang-orang dan perilaku yang dapat diamati. Pendekatan penelitian ini menggunakan content analysis atau analisis isi. Fraenkel dan Walken (2007) content analysis is a technique that enables researchers to study human behavior in an indirect way, through an analysis of their communication it is just what its name implies: the analysis of the usually, but not necessarily, written contents of a communication. Metode content analysis atau analisis isi yang digunakan untuk menelaah isi dari suatu dokumen, dalam penelitian ini dokumen yang dimaksud adalah buku teks bahasa Indonesia dan bahasa Sunda. Oleh karena itu, penelitian ini mendeskripsikan atau menggambarkan apa yang menjadi masalah, kemudian menganalisis dan menafsirkan data yang ada.

Teknik pegumpulan data yang digunakan dalam penelitian ini adalah teknik catat, karena data-datanya berupa teks. Adapun langkah-langkah dalam pengumpulan data adalah sebagai berikut: membaca buku teks secara berulang-ulang, mencatat kata-kata yang mengandung unsur pembeda dari fonologi yaitu unsur vokal dan konsonan.

Teknik analisis data yang digunakan dalam penelitian ini menggunakan model analisis mengalir, yang meliputi tiga 
Lutfi Syauki Faznur ${ }^{1)}$, Didah Nurhamidah²): Komparasi Fonem Bahasa Sunda dan Bahasa Indonesia Dalam Buku Teks

Website : https://jurnal.umj.ac.id/index.php/penaliterasi Email :penaliterasi@umj.ac.id

komponen, yaitu 1) reduksi data; 2) penyajian data; dan 3) penarikan simpulan. Analisis model mengalir mempunyai tiga komponen yang saling terjalin dengan baik, yaitu sebelum, selama dan sesudah pelaksanaan pengumpulan data. Penjelasannya sebagai berikut.

1. Reduksi data

Pada langkah ini data yang diperolah dicatat dalam uraian yang terperinci. Dari data-data yang sudah dicatat tersebut, kemudian dilakukan penyederhanaan data. Data-data yang dipilih hanya data yang berkaitan dengan masalah yang akan dianalisis, dalam hal ini tentang analisis konstratif bahasa Indonesia dan bahasa Sunda. Informasi-informasi yang pengacu pada permasalahan itulah yang menjadi data dalam penelitian ini.

2. Sajian data

Pada langkah ini, data-data yang sudah ditetapkan kemudian disusun secara teratur dan terperinci agar mudah dipahami. Data-data tersebut kemudian dianalisis sehingga diperoleh deskripsi tentang analisis konstratif bahasa Sunda dan bahasa Indonesia serta implikasinya bagi pendidikan.

3. Penarikan simpulan/ verifikasi

Pada tahap ini dibuat kesimpulan tentang hasil dari data yang diperoleh sejak awal penelitian. Kesimpulan ini masih memerlukan adanya verifikasi (penelitian kembali tentang kebenaran laporan) sehingga hasil yang diperoleh benar-benar valid.

Prosedur penelitian yang dilakukan peneliti terdiri dari beberapa tahap sebagai berikut.

1. Pengumpulan data

Pada tahap ini peneliti mengumpulkan data berupa kutipankutipan yang menunjukkan analisis kontratif fonologi bahasa Sunda dan bahasa Indoensia.

2. Penyeleksian data
Data-data yang telah dikumpulkan, kemudian diseleksi serta dipilah-pilah mana saja yang akan dianalisis.

3. Menganalisis data yang telah diseleksi.

4. Membuat laporan penelitian.

Laporan penelitian merupakan tahap akhir dari serangkaian proses. merupakan tahap penyampaian data-data yang telah dianalisis, dirumuskan, dan ditarik kesimpulan.

\section{HASIL DAN PEMBAHASAN}

Fonemis dalam bahasa sunda terdiri dari konsonan dan vokal, begitu pula dalam bahasa Indonesia, akan tetapi adapula perbedaan-perbedaan vokal dan konsonan dari kedua bahasa tersebut. Di bawah ini dapat dilihat beberapa perbedaan bahasa sunda dan bahasa Indonesia berdasarkan distribusi konsonan dan vokal, serta deretan vokal dan konsonan.

\section{Vokal}

\section{a. Jenis Vokal}

Terdapat tujuh buah vokal dalam bahasa sunda, yaitu: /a/ [a], /i/ [i], $/ \mathrm{u} /[\mathrm{u}], / e^{\prime} /[\varepsilon], / \mathrm{o} /[\mathrm{o}], / \mathrm{eu} /$ [ö], dan /e/ [c], (Pusat Pembinaan dan Pengembangan Bahasa:1983). sedangkan terdapat lima buah vokal dalam bahasa Indonesia, dapat diperjelas dalam tabel di bawah ini:

Tabel 5

Perandingan Vokal Bahasa Sunda dengan Bahasa Indonesia

\begin{tabular}{|l|l|}
\hline $\begin{array}{l}\text { Vokal Bahasa } \\
\text { Sunda }\end{array}$ & $\begin{array}{l}\text { Vokal bahasa } \\
\text { Indonesia }\end{array}$ \\
\hline$/ \mathrm{a} /$ & $/ \mathrm{a} /$ \\
\hline$/ \mathrm{i} /$ & $/ \mathrm{i} /$ \\
\hline$/ \mathrm{u} /$ & $/ \mathrm{u} /$ \\
\hline$/ e ́ \mathrm{l} /$ & $\ldots$ \\
\hline$/ \mathrm{o} /$ & $/ \mathrm{o} /$ \\
\hline$/ \mathrm{e} \mathrm{u} /$ & $\ldots$ \\
\hline
\end{tabular}


Lutfi Syauki Faznur ${ }^{1)}$, Didah Nurhamidah²): Komparasi Fonem Bahasa Sunda dan Bahasa Indonesia Dalam Buku Teks

Website : https://jurnal.umj.ac.id/index.php/penaliterasi Email :penaliterasi@umj.ac.id

/e/ $/$ /e/
Adapun untuk lebih jelasnya
dapat dipaparkan ke dalam contoh
pemakaian dalam sebuah kata di
bawah ini:

Tabel 6

\begin{tabular}{|l|l|l|l|}
\hline $\begin{array}{l}\text { Vokal } \\
\text { Bahasa } \\
\text { Sunda }\end{array}$ & $\begin{array}{l}\text { Kata } \\
\text { dalam } \\
\text { bahasa } \\
\text { Sunda }\end{array}$ & $\begin{array}{l}\text { Kata } \\
\text { dalam } \\
\text { bahasa } \\
\text { Indonesia }\end{array}$ & $\begin{array}{l}\text { Kata } \\
\text { dalam } \\
\text { bahasa } \\
\text { Indonesia }\end{array}$ \\
\hline /a/ & /aya/ & /a/ & /ada/ \\
\hline$/ \mathrm{i} /$ & /rit/ & /i/ & /irit/ \\
\hline /u/ & /urut/ & /u/ & /uang/ \\
\hline /é/ & /haté/ & $\ldots$ & $\ldots$ \\
\hline /o/ & /asok/ & /o/ & /orang/ \\
\hline /eu/ & /seuneu/ & $\ldots$ & $\ldots$ \\
\hline /e/ & /palem/ & /e/ & /kembang/ \\
\hline
\end{tabular}

Perandingan Kata Vokal Bahasa

Sunda dengan Bahasa Indonesia

\section{b. Distribusi Vokal}

Distribusi vokal dalam bahasa Sunda berada pada posisi awal, tengah dan akhir, terkecuali fonem /e/ yang tidak bisa berada pada posisi akhir kata. Walaupun demikian, pada bahasa Sunda juga terkadang ditemukan fonem /e/ yang berada di akhir kata, tetapi biasanya bunyi yang dihasilkan berubahb menjadi /eu/ (Robins:1983).

Agar lebih jelas mengenai distribusi vokal, maka penulis membuat tabel perbandingan distribusi vokal sebagai berikut:

Tabel 7

Distribusi Vokal Bahasa Sunda

\begin{tabular}{|c|c|c|c|}
\hline \multirow{2}{*}{$\begin{array}{l}\text { Fonem } \\
\text { Vokal }\end{array}$} & \multicolumn{3}{|c|}{ Posisi } \\
\hline & Awal & Tengah & Akhir \\
\hline
\end{tabular}

\begin{tabular}{|c|c|c|c|}
\hline /a/ & /a bdi/ & /ka tuhu/ & $/ \mathrm{wars} \mathbf{a} /$ \\
\hline /i/ & $/ \mathbf{i} \mathrm{mah} /$ & /bi sa/ & /nyeri / \\
\hline$/ \mathrm{u} /$ & /u yah/ & /ku lit/ & $/$ tilu / \\
\hline /é/ & /é ra/ & /gé gél/ & /carogé/ \\
\hline$/ 0 /$ & $/ 0 \mathrm{ray} /$ & $/ \mathrm{s} \mathbf{0} \mathrm{ca} /$ & /nagaro / \\
\hline$/ \mathrm{eu} /$ & /eu eut/ & /seu ri/ & /heunteu / \\
\hline$/ \mathrm{e} /$ & /e ndog/ & /le res/ & |/-.-.--/ \\
\hline
\end{tabular}

Sedangkan dalam bahasa Indonesia, semua vokal bisa berada pada posisi awal, tengah dan akhir. Contoh dalam kata-kata tersebut bisa dilihat dalam tabel di bawah ini:

Tabel 8

Distribusi Vokal Bahasa Indonesia

\begin{tabular}{|l|l|l|l|}
\hline \multirow{2}{*}{$\begin{array}{l}\text { Fone } \\
\text { Voka } \\
\mathbf{l}\end{array}$} & \multicolumn{3}{|c|}{ Posisi } \\
\cline { 2 - 4 } & Awal & Tengah & Awal \\
\hline$/ \mathrm{a} /$ & $/ \mathbf{a} \mathrm{ku} /$ & $/ \mathrm{ka} \mathrm{ca} /$ & $/ \mathrm{masa} /$ \\
\hline$/ \mathrm{i} /$ & $/ \mathbf{i} \mathrm{kat} /$ & $/ \mathrm{bi} \mathrm{la} /$ & $/ \mathrm{kaki} /$ \\
\hline$/ \mathrm{u} /$ & $/ \mathbf{u ~ a n g} /$ & $/ \mathrm{su} \mathrm{lit} /$ & $/ \mathrm{malu} /$ \\
\hline$/ \mathrm{o} /$ & $\begin{array}{l}/ \mathbf{o} \mathrm{rang} \\
/\end{array}$ & $/ \mathrm{ko} \mathrm{ko} /$ & $/ \mathrm{saw} /$ \\
\hline /e/ & $\begin{array}{l}\text { /e } \mathrm{mbe} \\
\mathrm{r} /\end{array}$ & $\begin{array}{l}/ \text { le luasa } \\
/\end{array}$ & $/ \mathrm{kue} /$ \\
\hline
\end{tabular}

\section{c. Deretan Vokal}

Menurut (Lembaga Basa dan Sastra Sunda:1975), deretan vokal bahasa Sunda ada yang memiliki dua deretan vokal yang berada dalam satu kata misalnya:

- Vokal tinngi dan tinggi depan $\boldsymbol{i} i$

Contoh: sii h /siih/ [si?ih]

'cakar ayam'

- Vokal tinggi dan tengah depan ie

Contoh: kier /kier/ [ $\left[\mathrm{ki}^{\mathrm{y}}\right.$ er $]$

'mondar-mandir'

- Vokal depan dan pusat tinggi ieu

Contoh: sieu n /sieun/ [si $\mathrm{si}^{\mathrm{y}}$ ön] 'takut' 
Lutfi Syauki Faznur ${ }^{1)}$, Didah Nurhamidah²): Komparasi Fonem Bahasa Sunda dan Bahasa Indonesia Dalam Buku Teks

Website : https://jurnal.umj.ac.id/index.php/penaliterasi Email :penaliterasi@umj.ac.id

- Vokal depan tinggi dan vokal tengah belakang $\boldsymbol{i o}$

Contoh: mios /mios/ [ $\mathrm{mi}^{\mathrm{y}}$ os $]$ 'pergi'

- Vokal depan dan belakang tinggi iu Contoh: iu ran /iuran/ [i $i^{y}$ uran] 'sumbangan'

- Vokal depan tinggi dan rendah pusat $\boldsymbol{i} \boldsymbol{a}$

Contoh: mia ng /mia ng/ [mian] 'pergi'

- Vokal tengah dan tengah depan é é Contoh: éé /éé/ $[\varepsilon \varepsilon]$ 'buang air besar'

- Vokal depan dan belakang tengah éo

Contoh: kéong /kéong/

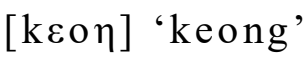

- Vokal depan tengah dan pusat rendah éa

Contoh: éa k /éak/ [éak] 'tertawa'

- Vokal tengah dan tengah pusat $\boldsymbol{e} e$ Contoh: hee h /heeh/ [he?eh] 'ya'

- Vokal Pusat dan depan tinggi eui

Contoh: leui r /leuir/ [löir] 'telat'

- Vokal Pusat dan pusat tinggi еиеи Contoh: seueul/seueul/ [sö?öl] 'mual'

- Vokal pusat tinggi dan pusat rendah eua

Contoh: teua s /teuas/ [töas] 'keras'

- Vokal tengah belakang dan depan tinggi oi

Contoh: doi p /doip/ [doip] 'lemah'

- Vokal belakang dan depan tengah $\boldsymbol{o}$ é

Contoh:

koé t

/koét/ [ko $\left.{ }^{\mathrm{w}} \varepsilon \mathrm{t}\right]$ 'cakar'

-Vokal tengah dan tengah belakang $\boldsymbol{\text { oo }}$

Contoh: goo ng /goong/ [go?oๆ] 'gong'

- Vokal tengah dan tinggi belakang $\boldsymbol{o u}$

Contoh: sou n /soun/

[so?un] 'bihun'

-Vokal tengah belakang dan rendah pusat oa

Contoh:

moa 1

/moal/ $\left[\mathrm{mo}^{\mathrm{w}} \mathrm{al}\right]$ 'tidak akan'

-Vokal belakang dan depan tinggi $u \boldsymbol{i}$

Contoh: ui h /uih/ $\left[\mathrm{u}^{\mathrm{w}}\right.$ ih $]$ 'pulang'

-Vokal belakang tinggi dan depan tengah óe

Contoh: poé k /poék/ [po " ék] 'gelap'

- Vokal belakang dan pusat tinggi иеu

Contoh: cueu t /cueut/ [ $\mathrm{cu}^{\mathrm{w}} \mathrm{öt}$ ' 'condong'

-Vokal belakang dan belakang tinggi u u

Contoh: huu t /huut/ [hu?ut] 'dedak'

- Vokal Belakang tinggi dan pusat rendah $\boldsymbol{u} \boldsymbol{a}$

Contoh: tua ng /tuang/ [tu ${ }^{\text {w }}$ a $]$ 'makan'

- Vokal Pusat Rendah dan Depan Tinggi $\boldsymbol{a} \boldsymbol{i}$

Contoh: lai n /lain/ [lain] 'bukan'

- Vokal Pusat Rendah dan Depan Tengah $\boldsymbol{a} \boldsymbol{e}$

Contoh: laé $r$ /laér/ [laer] 'jauh'

- Vokal rendah dan tinggi pusat $\boldsymbol{a} e \boldsymbol{u}$

Contoh: baeud /baeud/

[baöd] 'cemberut'

- Vokal pusat dan tengah belakang ao

Contoh: mao k /maok/ [maok] 'maling'

- Vokal Pusat dan Belakang Tinggi au

Contoh: lau k /lauk/ [lauk] 'ikan'

- Vokal Pusat dan Rendah a a 
Lutfi Syauki Faznur ${ }^{1)}$, Didah Nurhamidah²): Komparasi Fonem Bahasa Sunda dan Bahasa Indonesia Dalam Buku Teks

Website : https://jurnal.umj.ac.id/index.php/penaliterasi Email :penaliterasi@umj.ac.id

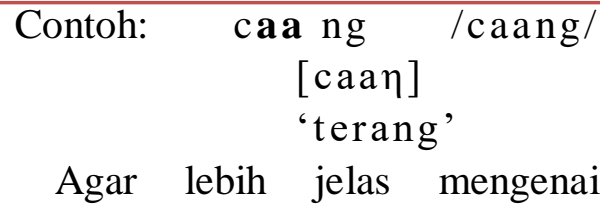
deretan vokal, maka penulis membuat tabel sebagai berikut:

Tabel 9

Deretan Vokal

\begin{tabular}{|l|l|l|l|l|l|l|l|}
\hline $\begin{array}{l}\text { Vo } \\
\text { ka } \\
\text { l }\end{array}$ & I & E & C & Ö & O & U & A \\
\hline I & Ii & - & $\begin{array}{l}\text { I } \\
\text { c }\end{array}$ & i ö & Io & $\begin{array}{l}\text { I } \\
\text { u }\end{array}$ & Ia \\
\hline E & - & E $\varepsilon$ & - & - & Eo & - & Ea \\
\hline C & - & - & C & - & - & - & - \\
c & & & & & \\
\hline Ö & Öi & - & - & Öö & - & - & Öa \\
\hline O & Oi & $\begin{array}{l}\text { o } \\
\varepsilon\end{array}$ & - & - & oo & O & oa \\
u & \\
\hline U & Ui & $\begin{array}{l}\text { u } \\
\varepsilon\end{array}$ & - & u ö & - & $\begin{array}{l}\text { U } \\
\text { u }\end{array}$ & ua \\
\hline A & ai & $\begin{array}{l}\text { a } \\
\varepsilon\end{array}$ & - & a ö & ao & $\begin{array}{l}\text { A } \\
\text { u }\end{array}$ & aa \\
\hline
\end{tabular}

Dari paparan di atas, sangatlah jelas bahwa kemungkinan deretan vokal bahasa Sunda ada 29 buah. Sedangkan dalam bahasa Indonesia kata yang memiliki dua deretan vokal itu disebut dengan diftong. Diftong dalam bahasa Indonesia adalah /au/ seperti pada kerbau dan harimau, /ai/ pada landai dan cukai. Apabila ada dua vokal yang berurutan, namun yang pertama terletak pada suku kata yang berlainan dari yang kedua, maka di situ tidak ada diftong. Jadi vokal /au/ dan /ai/ pada kata bau dan lain bukanlah diftong.

\section{Konsonan}

\section{a. Jenis Konsonan}

Terdapat 18 konsonan dalam bahasa Sunda, yaitu /b/ [b], /c/ [c], /d/ [d], /g/ [g], /h/ [h], /j/ [j], /k/ $[\mathrm{k}], / 1 /[1], / \mathrm{m} /[\mathrm{m}], / \mathrm{n} /[\mathrm{n}], / \mathrm{ny} /$ $[\tilde{\mathrm{n}}], / \mathrm{ng} /[\eta], / \mathrm{p} /[\mathrm{p}], / \mathrm{r} /[\mathrm{r}], / \mathrm{s} /$ $[\mathrm{s}], / \mathrm{t} /[\mathrm{t}], / \mathrm{w} /[\mathrm{w}], \mathrm{dan} / \mathrm{y} /[\mathrm{y}]$.

Namun, akibat pengaruh bahasa asing, dalam bahasa Sunda pun adanya konsonan /f/ [f], /v/ [v], dan /z/ [z].

Dapat diperjelas dalam tabel berikut ini:

\section{Tabel 10}

Perbandingan Konsonan Bahasa

Sunda dengan Bahasa Indonesia

\begin{tabular}{|l|l|}
\hline $\begin{array}{l}\text { Konsonan } \\
\text { Bahasa Sunda }\end{array}$ & $\begin{array}{l}\text { Konsonan } \\
\text { bahasa } \\
\text { Indonesia }\end{array}$ \\
\hline$/ \mathrm{b} /$ & $/ \mathrm{b} /$ \\
\hline$/ \mathrm{c} /$ & $/ \mathrm{c} /$ \\
\hline$/ \mathrm{d} /$ & $/ \mathrm{d} /$ \\
\hline$\ldots$ & $/ \mathrm{f} /$ \\
\hline$/ g /$ & $/ \mathrm{g} /$ \\
\hline$/ \mathrm{h} /$ & $/ \mathrm{h} /$ \\
\hline$/ \mathrm{j} /$ & $/ \mathrm{j} /$ \\
\hline$/ \mathrm{k} /$ & $/ \mathrm{k} /$ \\
\hline$/ \mathrm{l} /$ & $/ \mathrm{l} /$ \\
\hline$/ \mathrm{m} /$ & $/ \mathrm{m} /$ \\
\hline$/ \mathrm{n} /$ & $/ \mathrm{n} /$ \\
\hline$/ \mathrm{ny} /$ & $\ldots$ \\
\hline$/ \mathrm{ng} /$ & $\ldots$ \\
\hline$/ \mathrm{p} /$ & $/ \mathrm{p} /$ \\
\hline$\ldots$ & $/ \mathrm{q} /$ \\
\hline$/ \mathrm{r} /$ & $/ \mathrm{r} /$ \\
\hline$/ \mathrm{s} /$ & $/ \mathrm{s} /$ \\
\hline$/ \mathrm{t} /$ & $/ \mathrm{t} /$ \\
\hline$\ldots$ & $/ \mathrm{v} /$ \\
\hline$/ \mathrm{w} /$ & $/ \mathrm{w} /$ \\
\hline$\ldots$ & $/ \mathrm{x} /$ \\
\hline$/ \mathrm{y} /$ & $/ \mathrm{y} /$ \\
\hline$\ldots$ & $/ \mathrm{z} /$ \\
\hline & \\
\hline
\end{tabular}

Berdasarkan tabel di atas, dapat dilihat bahwa ada beberapa konsonan bahasa Sunda yang tidak ada dalam bahasa Indonesia, begitupun sebaliknya ada beberapa konsonan yang ada dalam bahasa Indonesia yang tidak ada dalam 
Lutfi Syauki Faznur ${ }^{1)}$, Didah Nurhamidah²): Komparasi Fonem Bahasa Sunda dan Bahasa Indonesia Dalam Buku Teks

Website : https://jurnal.umj.ac.id/index.php/penaliterasi Email :penaliterasi@umj.ac.id

bahasa Sunda. Dalam bahasa Sunda

\begin{tabular}{|c|c|c|c|c|c|c|}
\hline $\begin{array}{l}\text { Vokal } \\
\text { Bahasa }\end{array}$ & $\begin{array}{l}\text { Kata } \\
\text { dalam }\end{array}$ & $\begin{array}{l}\text { Kat } \\
\mathbf{a}\end{array}$ & $\begin{array}{l}\text { Kata } \\
\text { dalam }\end{array}$ & $\begin{array}{l}\text { Tabel } 11 \\
\text { Perbandingan }\end{array}$ & Kata & Konsonan \\
\hline Sunda & $\begin{array}{l}\text { bahasa } \\
\text { Sunda }\end{array}$ & $\begin{array}{l}\text { dala } \\
\text { m }\end{array}$ & $\begin{array}{l}\text { bahasa } \\
\text { Indonesi }\end{array}$ & $\begin{array}{l}\text { Bahasa Sunda } \\
\text { Indonesia }\end{array}$ & dengan & Bahasa \\
\hline
\end{tabular}

yang tidak ada dalam bahasa Sunda yaitu /z/, /x/, /v/, /q/, dan /f/.

Tabel 11

\section{Perbandingan Kata Konsonan Bahasa Sunda dengan Bahasa} KESIMPULAN

Berdasarkan pemaparan penelitian di atas, mengenai fonemfonem bahasa Sunda, maka dapat disimpulkan bahwa fonem yang terdapat pada bahasa Sunda terdapat tujuh buah vokal, yaitu /a/ [a], /i/ [i], /u/ [u],

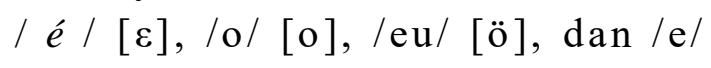
[c] sedangkan dalam bahasa Indonesia terdapat lima vokal yaitu [a], [i], [u], [e], [o]. Pengklasifikasian jenis vokal dapat ditentukan oleh tiga hal, yaitu: posisi bibir, maju-mundurnya lidah, dan tinggi rendahnya lidah.

Terdapat 18 konsonan dalam bahasa sunda, yaitu: /b/ [b], /c/ [c], $/ \mathrm{d} /[\mathrm{d}], / \mathrm{g} /[\mathrm{g}], / \mathrm{h} /[\mathrm{h}], / \mathrm{j} /[\mathrm{j}], / \mathrm{k} /$ $[\mathrm{k}], / \mathrm{l} /[\mathrm{l}], / \mathrm{m} /[\mathrm{m}], / \mathrm{n} /[\mathrm{n}], / \mathrm{ny} /$

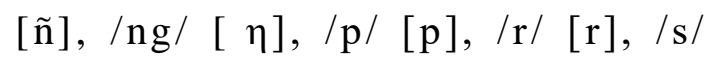
$[\mathrm{s}], / \mathrm{t} /[\mathrm{t}], / \mathrm{w} /[\mathrm{w}], \mathrm{dan} / \mathrm{y} /[\mathrm{y}]$. Sedangkan dalam bahasa Indonesia ada 21 konsonan yaitu b/ [b], /c/ [c], /d/ [d], /f/ [f], /g/ [g], /h/ [h],/j/ [j], $/ \mathrm{k} /[\mathrm{k}], / \mathrm{l} /[\mathrm{l}], / \mathrm{m} /[\mathrm{m}], / \mathrm{n} /[\mathrm{n}]$, $/ \mathrm{p} /[\mathrm{p}], / \mathrm{q} /[\mathrm{q}], / \mathrm{r} /[\mathrm{r}], / \mathrm{s} /[\mathrm{s}], / \mathrm{t} /$ $[\mathrm{t}], / \mathrm{v} /[\mathrm{v}], / \mathrm{w} /[\mathrm{w}], / \mathrm{x} /[\mathrm{x}], / \mathrm{y} /$ [y], dan /z/ [z]. Pengklasifikasian kosonan dapat ditentukan oleh tiga hal, yaitu: keadaan pita suara, artikulator dan titik artikulasi.

Distribusi konsonan pada bahasa Sunda berada pada posisi awal, tengah, dan akhir, kecuali vonem /e/ yang tidak biasa berada pada posisi akhir kata. walaupun demikian, pada bahasa sunda juga terkadang ditemukan fonem /e/ yang 
Lutfi Syauki Faznur ${ }^{1)}$, Didah Nurhamidah²): Komparasi Fonem Bahasa Sunda dan Bahasa Indonesia Dalam Buku Teks

Website : https://jurnal.umj.ac.id/index.php/penaliterasi Email :penaliterasi@umj.ac.id

berada di akhir kata, tapi biasanya bunyi yang dihasilkan berubah menjadi /eu/. Sedangkan distribusi konsonan bahasa Sunda biasanya menduduki posisi awal, tengah, dan akhir kata.

Kemungkinan deretan vokal bahasa sunda ada 29 buah. Tetapi, ada sebagian vokal yang tidak bisa berderet dengan vokal-vokal lainnya, yaitu: /i é/

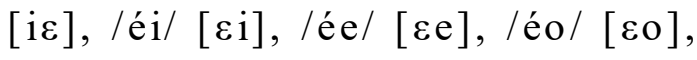
$/$ éu/ $[\varepsilon u], / e i /[e i], / e e ́ /[e \varepsilon]$, /eeu/ [eö], /eo/ [eo], /eu/ [eu], /oe/ [oe], /oeu/ [oö], /ue/ [ue], /uo/ [uo], dan /ae/ [ae]. Sedangkan dalam bahasa Indonesia, kata yang memiliki deretan kata disebut dengan diftong. Diftong dalam bahasa Indonesia adalah /au/ seperti pada kerbau dan harimau, /ai/ pada landai dan cukai. Apabila ada dua vokal yang berurutan, namun yang pertama terletak pada suku kata yang berlainan dari yang kedua, maka di situ tidak ada diftong. Jadi vokal /au/ dan /ai/ pada kata bau dan lain bukanlah diftong.

Simpulan lainnya, ternyata bahasa Sunda sangatlah kaya akan kosakata bahkan ada sebagian kata yang tidak ada padanannya pada bahasa Indonesia, seperti: 'butbet', 'gebrug', 'gejr ét', dan masih banyak lagi, sehingga penulis hanya mencantumkan fonem- fonem pada kumpulan kata yang ada padanannya dalam bahasa Indonesia.

\section{REFERENSI}

Chaer, Abdul. 2007. Linguistik Umum, Jakarta: Rineka Cipta

Lembaga Basa dan Sastra Sunda. 1975. Kamus Basa Sunda. Bandung: Tarate.

Pranowo. 1996. Analisis Pengajaran Bahasa, Yogyakarta: Gadjah Mada University Press

Pusat Pembinaan dan Pengembanan Bahasa Departemen Pendidikan dan Kebudayaan. 1997. Kosakata Bahasa Sunda dalam Media Masa. Jakarta: Pusat Pembinaan dan Pengembangan Bahasa

Robins, r.h. 1983. Sistem dan Struktur Bahasa Sunda. Jakarta: IKAPI.

Fraenkel, J. P. \& Wallen N. E. (2008). How to design and Evaluate Research in Education. New York: McGraw-Hill Companies, Inc.

Moleong, Lexy. J. 2007. Metode Penelitian Kualitatif. Bandung: PT. Remaja Rosda Karya. 